\title{
A Study on the Construction of Modern University System
}

\author{
Yuting He \\ School of Economics and Management \\ Shenyang Ligong University \\ Shenyang, China \\ hyt1975@163.com
}

\author{
Xue Min \\ School of Economics and Management \\ Shenyang Ligong University \\ Shenyang, China \\ Anjingxue0112@126.com
}

\begin{abstract}
Establishing the modern university system in accordance with national condition is the core of our current higher education reform. On the basis of analyzing the meaning of modern university system, this paper briefly analyzes the problems existing in the process of establishing modern university system and focuses on the ways to solve these problems.
\end{abstract}

Keywords-modern university system; higher education; reform

\section{INTRODUCTION}

After the reform and opening, especially entering into the new century, China has made historical achievements in developing higher education, has gained remarkable progresses on reform, and has entered into an international accepted stage of popularization. However, China's higher education is still confronted with a lot of new situations, new contradictions, new problems, and several difficulties that restrict its development. Among them, establishing the modern university system in accordance with national condition is the core of our current higher education reform. So, establishing modern university system with Chinese characteristic, which is proposed in The outline of the national medium and long term program for education reform and development, has aroused wide attention of the whole society, and has become an important task for colleges and universities. At present, the construction of our modern university system is still in its beginning stage. So, we need to systematically think and explore the idea, mode, and frame of the modern university system. On the basis of parsing the meaning of modern university system, this paper briefly analyzes the problems existing in the process of establishing modern university system and focuses on the ways to solve these problems.

\section{THE MEANING OF MODERN UNIVERSITY EDUCATION}

Throughout the developing process of the university system, medieval university system can be considered as the "rigin" of the modern university system. Medieval university, through a comparatively comprehensive system construction, has become a firm, specialized, and independent academic and educational institution, which is the direct origin of modern university. In the course of university's development, as the essence of the university system, autonomy and academic freedom has been extended to today. Academic freedom is used to adjust the relations of university organizations, while university autonomy is used to against the pressure from the outside.
University autonomy and academic freedom is the idea and the frame of modern university, which reflect the essences and features of a university, form the basic connotation of the university system, and continue the life and energy of one university, a specific institution.

We can understand university system from two aspects. The first one is, from macro perspective, a national higher education system which includes the school-running system, investment system, and administration system on the national level. Macro university system reflects more on the demand of the outside society; it often shows the characteristic of the era. The second one is micro system which mainly refers to the inner construction and system of the university; it is the system guarantee to sustain the operation and function of the university. Micro university system reflects more on the characteristic of university and its subject logic.

\section{THE ESTABLISHMENT OF MODERN UNIVERSITY SYSTEM WITH CHINESE CHARACTERISTICS}

At present, the systemic problem occurred in China's universities include: (1) University's autonomy is limited due to the lack of transformation of the government function and its managements. (2) The third-party agencies, independent of government and school, are incomplete and unsound in system. (3) Higher education laws and regulations are incomplete. (4) Internal regulations of the colleges and universities are lagged. (5) Fulfillment of "professor governing academic studies" is less than complete, improvements of school democratic management is wanted.

The establishment of China's modern university system needs to be taken in the specific social development stage, under the international background, and be based on the national conditions with advanced ideas and experiences of foreign university for the achievement of our special modern university system, thus to establish a running-school system which can cater to the needs of the era as well as the pattern of higher education development. The core of establishing China's modern university system is to face the society, realize school autonomy and democratic management, and achieve the harmonious development between university and government, between the universities as well as between university and society. And the essence is university's autonomy and academic freedom, which is the basic element to ensure the sound development of the university. 
The framework of modern university system includes two parts: the in-school core and the off-school extension. The inschool core part is the basis, which needs to strengthen party community leadership, president in-charge system, professor governing academic studies, democratic management. The offschool extension is the external conditions of development, which needs to establish the sound government micro management system of government, market moderate adjusting system, society extensive participation system and university running autonomy system.

\section{A. Structuring Positive External Conditions}

1) Strengthening government micro management system, promoting the separation of government and school as well as the separation of management and conduction

Government needs to define management authority and duty, pay more attention on the guide and management of the teaching and school at a micro level, introducing flexible and efficient system, gaining the university system a refreshing vitality, unifying autonomy, micro management and market adjustment so as to structure a new management pattern. On promoting the regulation mode, government should focus on guiding plan, devolution of power and gradually extend the autonomy of school. While carrying on teaching evaluation and improving running school transparency, university should run school autonomously, handle university internal affairs autonomously, and give university more autonomy on enrollment and charge and less interfere especially on making assessment standard, specialty setting and independent recruitment to further inspire the activity and creativity of running school. Meanwhile, it also helps to ensure the democratic freedom in university.

\section{2) Perfect intermediaries to coordinate between} universities and government

Governments and universities are obligated to public tidings such as quality, construction, curriculum and teaching programme of universities. Therefore, society can have a better understanding of the information which is convenient for supervision and operation. Meanwhile, intermediaries should be cultivated while the third-part evaluation systems should be introduced. The evaluation intermediary serves a bridge among governments, society and universities. It can consult for government and society to determine the appropriation and investment orientations, and keep universities relatively independent from external interference. The third-part evaluation organizations, usually non-government groups, evaluate teaching and researching achievements of universities mainly from the perspectives of some singles including course standard which provides foundation for important subject selection and major research-based constructions. Likewise, they proactively offer information to play a better role as a social supervisor. An evaluation-based appropriation system should be established in which evaluation results and resource allocations are linked. And tidings, for example, evaluation results, financial statements and teaching researches ought to be opened to the public.

3) Promote the legislation of higher education and ensure the status of university's juridical persons
Sound higher education legislative system is the basis for administrating universities by law and the foundation for government to manage universities from a macroscopic view. To promote higher education legislation aims at offering institutions of modern university system with complete legal environment, so that to ensure the status of juridical persons by law. We should explicate the status, responsibilities and rights of the internal learning, and fundamentally strengthen the legal position, existing formation and operating system of 'professor scholarship', making it a sure bet that teachers are the subjects in the core teaching fields such as university orientation, course layout and resource distribution. It is the embodiment of administrating universities by law and the requirement for modern university system that government manages universities by law and the universities develops itself in accordance with law and internal institutions.

\section{B. Improve Internal Management Structure of Colleges and Universities}

1) Lay an emphasis on the construction of the theories on school management

The theories on school management contribute to the soul of the construction of modern university system, highly summarizing the faiths, goals and missions of universities, embodying a ferocious internal power which makes it more effective than the hard and fast institutions. Unique campus cultures, unwritten school regulations would enforce an immanent restriction upon the behaviors and ideologies of university members. Meanwhile, theories of school management would strive them for the university orientation, and naturally penetrate into the crowd by invisible influence, then become the common values and faiths. As a result, the entire university merges with powerful cohesion, encouraging the members work together for a common goal. In the process of building theories of school management, educational concepts and aims should be determined, setting marketoriented characteristic as the objective and establishing 'selfconsciousness of universities'. We should fully implement the value orientations of academic freedom in order to maintain the essential characteristic of universities.

\section{2) Consummate university institutions}

We should formulate and implement university institutions for the purpose of guaranteeing the school management open to the society by law. The university institutions are a major reflection of the principle 'administrate universities by law' as well as the important substance of university internal management. Firstly, the establishment of university institutions should abide by the regulations and laws for higher education and make decisions on major issues such as school orientation, internal management system, decision-making system as well as the obligations and rights of universities, government and society. All the movements should be restrained within the filed empowered by law with physical circumstances taken into account. Secondly, university institutions plays a role as 'university Constitution' serving the basis in university internal regulative activities. They should be strictly implemented and observed. In order to achieve greater effect, government, the administrator of universities, is obligated to supervise. Lastly, university institutions should be 
adjusted and improved in line with the alterations of objective circumstances in the process of the implementation.

3) Consummate democratic administration and decisionmaking system

a) Insist and perfect principle liability system under Party committee

To further perfect principle liability system under Party committee requires clearly explicate the division of labor between Party and government, leadership decision-making mechanism and the liabilities of Party committee and principles. The leadership and decision-making power of Party committee should be demonstrated on great occasions for the pursuit of directivity, long-term effect and overall situation. In the meantime, the Party committee should lead the development and comprehensive work of universities and back principles to independently exercise rights. As juridical person of the school and major administrative director, the principle is the decision maker as well as the performer in the structure of university management, including administrating teaching activities, scientific researches and other executive work, also taking responsibilities for government, university Party committee and the entire crowd of teachers and students. The key to enhance and improve the principle liability mechanism under Party committee lies in the enforcement of executive leadership of principles. Therefore, it is badly in need to improve principle selection and appointment methods which should be determined both by government and university democratically and publicly.

\section{b) Feasibly advance 'professor leadership'}

We should fully rely on and make a sufficient use of the influence casted by professors in the scientific research and teaching democratic management to democratize and scientize the decision-making of higher educational administration. Professors' academic rights should be ensured, and the 'professor leadership' system of their own past should be reinforced, so as to bring their leadership, demonstrating in academic construction, scholarly evaluation and academic standardization establishment, into play, then warrant the learning nature of universities, at last complete transformation from execution-led management to a learning-led one. Make sure to empower academic board, teaching guiding committee and committee of administrative affairs as well as faculty and trade union congress to make them significant platforms for professor leadership and democratic administration. The influence of board of regents composed mainly of professors should be strengthened their decisions on administrative affairs implemented by executive organizations. Meanwhile, when it comes to faculty engagement and layoff, executive administrators merely have the right to dismiss executive staff while they are in the position to do the same thing to professors directly. Therefore, it is essential to construct a from top to bottom title evaluation system endowing a say with professors.

c) Amplify democratic decision-making procedure and mechanism

Universities are undertaking the mission to nurture talents, make researches and serve for society. We should claim the primacy of academic governing; make distinctions between crucial and common affairs, between executive and academic ones. Initiatives should be rendered to faculty and students in the school management so that fair participation can be achieved by listening to views of teachers and students on the issues concerning ideas of school management, teaching activities, scientific researches and university administration. Framed with committee mechanism, we should establish academic board and professor board composed mainly of professors in order to supervise committee of administrative affairs composed mainly of cadres and faculty and trade union congress composed mainly of the whole staff. Serving the basic form and authority for faculty to involve in democratic management, faculty and trade union congress extensively absorb the voices from the general public with an aim of ensuring that the entire staff can equally engage in the university administration.

\section{REFERENCES}

[1] Yang Tianping, "Institution Building for Modern Universities with Chinese Characteristics: Issues and Reflections," J. Modern University Education, Num.2, 2010, pp. 39-43.

[2] Peng Jiang, "A Review of the Studies about the Modern University System in China," J. Modern University Education, Num.2, 2005, pp. 52-57.

[3] Gu Xianlin, “The present dilemma of establishing modern university system," J. Academics, Num.5, May 2010, pp.109-112+285. 